\title{
MASS BALANCE SIMULATION FOR STEAM REFORMER IN DIRECT REDUCTION OF IRON ORE BY HYL III PROCESS.
}

\author{
Elhelw, H.* \\ Corresponding author Tel.: +201001708191 \\ E-mail address: heasham_abd@yahoo.com \\ *Faculty of Petroleum and Mining Engineering, Suez University, Suez, Egypt, \\ EZZ steel Operation
}

\begin{abstract}
HYL direct reduction of iron ore process uses a reducing gas composed of a mixture of $\mathrm{H}_{2}$ and $\mathrm{CO}$ in order to reduce iron oxide pellets to metallic iron (DRI). This process is mainly dependent on a reformer to supply the reducing gas. In the reformer, natural gas is catalytically converted into reducing gas by reaction with steam at a temperature of 800 to $850^{\circ} \mathrm{C}$ and pressure between 8 and 8.5 bars in the presence of Nickel based catalyst. In order to analyze the reformer operation, it is necessary to estimate the reformed gas composition for some specific process conditions.
\end{abstract}

The present work is based on the solution of a set of non-linear equations describing mass balances of carbon, hydrogen, oxygen and higher hydrocarbons, to enable the calculation of reformed gas composition for a steam reformer. The procedure can assist both process engineers tackling the problem of estimating output from a primary reformer at the design stage and plant operating engineers. The mass balance equations are solved by using the equilibrium constants for the reforming and water gas shift reactions. This includes simultaneously solving non-linear equations relating to the composition of reactants and other variables as temperature and pressure at which reactions take place. In addition, amount of carbon contained in natural gas compared to amount of steam used in steam reforming reaction is also considered during calculations. The basic requirements to establish the model are a set of reactions and values of equilibrium constants for the reforming and water gas shift reactions.

\section{Keywords}

Reformer, hydrocarbons, steam, equilibrium.

\section{INTRODUCTION}

There are different methods of iron ore reduction and new technologies developed for steel making in electric arc furnace (EAF). The main goal of the process development has been to avoid coke utilization and reduce the operating costs. In general, in a direct reduction process, oxygen is removed from iron oxide, in a furnace by using a reducing gas composed of $\mathrm{CO}$ and $\mathrm{H}_{2}$, if the cooling zone in the furnace is eliminated, the direct reduced iron (DRI) can be immediately briquetted into hot briquetted iron (HBI). The reducing gas can be obtained by reforming of hydrocarbons such as natural gas in a reformer using Nickel based catalyst. Processes using this general procedure are mainly [1]:

- Midrex direct reduction technology $\left(\mathrm{CO}_{2}\right.$ reformer $)$

- HYL direct reduction technology (steam reformer) 
- HYL direct reduction technology (zero reformer), the reforming process takes place by mixing natural gas and oxygen into the reduction furnace (in-situ reforming)

The HYL direct reduction process was the first direct reduction technology to operate successfully on industrial scale in the world (1957), proposing a technological concept that was a real solution to the iron needs of Hylsa in Mexico. Based on a fixed bed reactor concept, the results achieved with this technology were so attractive and innovative that other steelmaking companies acquired the HYL process license. Twenty-two reduction units were installed in different countries, with a total capacity of over 9 Million ton/year of DRI [2].

However, it was foreseen by HYL that the competitiveness of this technology would be limited due to its batch nature. For this reason, a research program was initiated in 1967 to develop a continuous (moving bed) process. The first industrial plant started producing in May 1980 in Hylsa Monterrey, Mexico. The new process concept led to higher plant productivity, superior DRI quality, lower energy consumption and a simpler plant operation [3].

One of the main advantages of the HYL [steam reforming] process is its configuration based on independent reducing gas generation and reduction sections. Under these conditions, the only requirement is an independent source to supply the $\mathrm{H}_{2}$ and CO needed for reduction. This is supplied from what is called a Steam Reformer which is fed with steam and NG at a certain condition of pressure and temperature to produce $\mathrm{H}_{2}$ and $\mathrm{CO}$ with no changes involved in the process scheme see figure 1 [3].

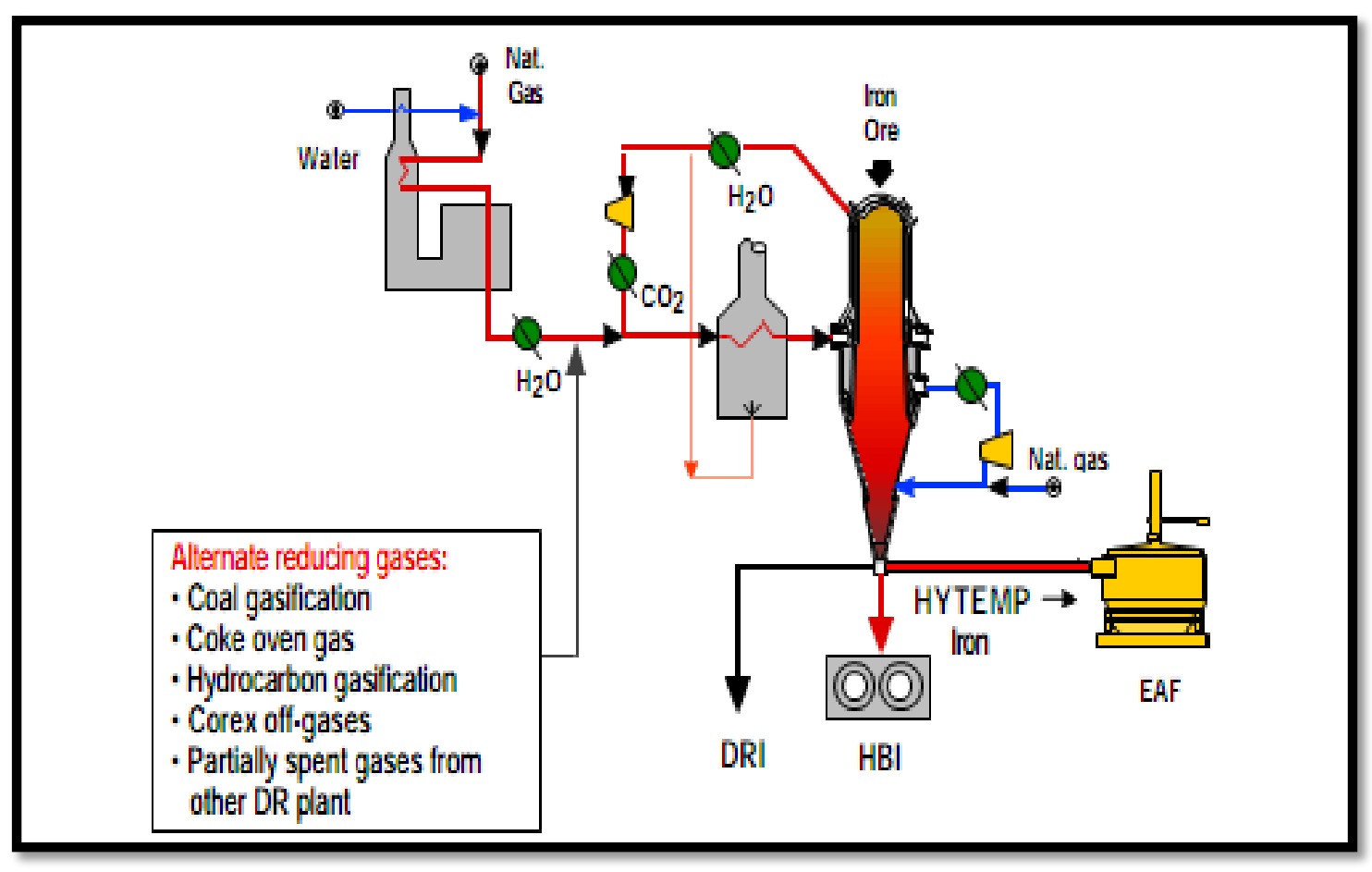

Fig. 1: HYL III (steam reforming) process scheme. [3] 
The present work concentrates on the study of steam reforming of natural gas, which is normally used for the production of reducing gas [3]. Operators of steam reformingbased plants prefer feedstock options to minimize operating costs and maximize operational flexibility [4].

Its aim is to estimate the reformed gas composition by knowing the following parameters:

- Temperature at which reaction is proceeding

- Pressure at which reaction is taking place

- Ratio of Steam to carbon contained in natural gas in the reformer feed stock.

The model that will be produced to estimate reformed gas composition is very important to assist both process engineers tackling the problem of estimating output from a primary reformer at the design stage and plant operating personnel to further tune their plant parameters to get the best gas quality and optimum energy consumption.

\subsection{Formulation of the Problem}

The two main reactions governing the process of steam methane reforming are:

$$
\begin{gathered}
\mathrm{CH}_{4}+\mathrm{H}_{2} \mathrm{O} \Leftrightarrow \mathrm{CO}+3 \mathrm{H}_{2} \\
\mathrm{CO}+\mathrm{H}_{2} \mathrm{O} \Leftrightarrow \mathrm{CO}_{2}+\mathrm{H}_{2} . .
\end{gathered}
$$

Reaction (1) is the reforming reaction while reaction (2) is the water gas shift reaction.

A comprehensive study was made on equilibrium conditions and other process parameters affecting the quality and condition of the gas produced by these reactions to better understand how steam reformer behavior can vary with varying these conditions.

As a general observation, only these two equations are necessary to represent the overall equilibrium process. In addition, when reforming higher saturated hydrocarbons and provided that contact time is long enough, the exit gas composition is that which approximately corresponds to the chemical equilibrium involving the methane-steam reforming and water gas shift reactions (equations 1 and 2).

Considering, as a first step, a reformer working at relatively high temperature and low pressure, in such a way that only $\mathrm{CO}, \mathrm{H}_{2}$ and water, besides $\mathrm{N}_{2}$ are the products. $\mathrm{CO}_{2}$ and $\mathrm{CH}_{4}$ cannot coexist under these conditions.

Therefore, the products at this step will be:

$\mathrm{CO}=\mathrm{C}($ All carbon becomes $\mathrm{CO})$

Total hydrogen:

$\mathrm{H}_{2}=\mathrm{H} / 2-\mathrm{H}_{2} \mathrm{O}=\mathrm{A}$ (all hydrogen becomes $\mathrm{H}_{2}$ except the Hydrogen combined as $\mathrm{H}_{2} \mathrm{O}$ ). 
$\mathrm{H}_{2} \mathrm{O}=\mathrm{O}-\mathrm{CO}=\mathrm{B}\left(\mathrm{H}_{2} \mathrm{O}\right.$ is equal to all the oxygen not combined as $\left.\mathrm{CO}\right)$.

\subsection{Definitions}

$\mathrm{C}_{1} \mathrm{C}_{2} \ldots$; $\mathrm{Cn}$ "mole fractions of $\mathrm{CH}_{4} \ldots \mathrm{Cn} \mathrm{H}_{2 \mathrm{n}+2}$ in the natural gas fed to the reformer".

$x_{\mathrm{CO}_{2}}, x_{\mathrm{CO}}, x_{\mathrm{H}_{2}}, x_{\mathrm{N}_{2}}, x_{\mathrm{H}_{2} \mathrm{O}}$ : "mole fractions of $\mathrm{CO}_{2}, \mathrm{CO}, \mathrm{H}_{2}, \mathrm{~N}_{2}$ and $\mathrm{H}_{2} \mathrm{O}$ respectively in the natural gas fed"

r: "Steam/carbon molar ratio fed to the reformer"

Then, the total carbon fed to the reformer will be:

$\mathrm{C}^{*}=\sum \mathrm{nC}_{\mathrm{n}}+\mathrm{X}_{\mathrm{CO}}+\mathrm{X}_{\mathrm{CO}_{2}}$

By definition, the steam fed will be:

$\mathrm{S}=\mathrm{r}^{*} \mathrm{C}$

Consequently, the total oxygen fed to the reformer will be:

$\mathrm{O}=x_{\mathrm{CO}}+2 x_{\mathrm{CO}_{2}}+\mathrm{r}^{*} \mathrm{C}+x_{\mathrm{H}_{2} \mathrm{O}}$

Finally, the inert gas will be the Nitrogen:

$\mathrm{I}=x_{N_{2}}$

Rearranging:

$\mathrm{CO}=\mathrm{C}$

$\mathrm{H}_{2}=\mathrm{H} / 2-\mathrm{O}+\mathrm{C}=\mathrm{A}$

$\mathrm{H}_{2} \mathrm{O}=\mathrm{O}-\mathrm{C}=\mathrm{B}$

$\mathrm{N}_{2}=\mathrm{I}$

As a second step, consider the actual conditions of temperature and pressure and the $\mathrm{CH}_{4}$ and $\mathrm{CO}_{2}$ in equilibrium at the stated conditions.

Methane and carbon dioxide will be produced according to equations (1) and (2):

The reforming reaction which will produce "W" moles of $\mathrm{CH}_{4}$ by reaction (1) and the water gas shift reaction producing " $Z$ " moles of $\mathrm{CO}_{2}$ as a consequence of reaction (2). The actual reformer outlet will comply with the new mass balance:

$\mathrm{CH}_{4}=\mathrm{W}$ moles $\mathrm{CH}_{4}$ produced by reaction (1)

$\mathrm{CO}_{2}=\mathrm{Z}$ moles $\mathrm{CO}_{2}$ produced by reaction (2) 
$\mathrm{CO}=\mathrm{C}-\mathrm{W}-\mathrm{Z}\left(\mathrm{CO}\right.$ consumed to produce $\mathrm{CH}_{4}$ and $\left.\mathrm{CO}_{2}\right)$.

$\mathrm{H}_{2}=\mathrm{A}-3 \mathrm{~W}+\mathrm{Z}\left(\mathrm{H}_{2}\right.$ consumed to produce $\mathrm{CH}_{4}$ and $\mathrm{H}_{2}$ as a result of $\mathrm{CO}_{2}$ generation $)$

$\mathrm{H}_{2} \mathrm{O}=\mathrm{B}+\mathrm{W}-\mathrm{Z}\left(\mathrm{H}_{2} \mathrm{O}\right.$ produced when generating $\mathrm{CH}_{4}$ and that consumed to form $\left.\mathrm{CO}_{2}\right)$

$\mathrm{I}=\mathrm{I}($ Inert gas does not react)

$\mathrm{F}_{\mathrm{t}}=(\mathrm{A}+\mathrm{B}+\mathrm{C}+\mathrm{I})-2 \mathrm{~W}=\mathrm{F}-2 \mathrm{~W}$

If $\mathrm{A}+\mathrm{B}+\mathrm{C}+\mathrm{I}=\mathrm{F}$; total flow.

\subsection{Basic Equations}

In this model, two main equations represent the equilibrium for steam methane reforming and water gas shift reaction. The equilibrium constant for reaction (1) is:

For reaction (2)

$$
K_{W}=\frac{\left(P_{\mathrm{H}_{2}}\right)^{3}\left(P_{\mathrm{CO}}\right)}{\left(P_{\mathrm{CH}_{4}}\right)\left(P_{\mathrm{H}_{2} \mathrm{O}}\right)}=\frac{\left(\mathrm{H}_{2}\right)^{3}(\mathrm{CO})}{\left(\mathrm{CH}_{4}\right)\left(\mathrm{H}_{2} \mathrm{O}\right)}\left(\frac{P_{t}}{F_{t}}\right)^{2}
$$

$$
K_{Z}=\frac{\left(P_{\mathrm{CO}_{2}}\right)\left(P_{\mathrm{H}_{2}}\right)}{\left(P_{\mathrm{CO}}\right)\left(P_{\mathrm{H}_{2} \mathrm{O}}\right)}=\frac{\left(\mathrm{CO}_{2}\right)\left(\mathrm{H}_{2}\right)}{(\mathrm{CO})\left(\mathrm{H}_{2} \mathrm{O}\right)} \ldots
$$

Substituting the functions of "W" and " $\mathrm{Z}$ for results in Reaction (1)

$$
K_{w}=\frac{(\mathrm{A}-3 \mathrm{~W}+\mathrm{Z})^{3}(\mathrm{C}-\mathrm{W}-\mathrm{Z})}{W(B+w-Z)} *\left(\frac{P_{t}}{F_{t}-2 W}\right)
$$

And Reaction (2)

$$
K_{Z}=\frac{\mathrm{Z}(\mathrm{A}-3 \mathrm{~W}+\mathrm{Z})}{(C-W-Z)(B+w-Z)}
$$

The equilibrium constant $\mathrm{K}$ for each reaction can be obtained from the following equation [5]

$$
\Delta \mathrm{G}^{\circ}=-\mathrm{RT} \ln \mathrm{K}
$$

Where $\Delta G^{\circ}$ is the change of standard free energy accompanying the reaction, in $\mathrm{Cal} / \mathrm{mol}, \mathrm{R}$ is the universal gas constant in $\mathrm{Cal} / \mathrm{deg} \cdot \mathrm{mol}$ and $\mathrm{T}$ is the absolute temperature in Kelvin.

The value of $\Delta \mathrm{G}^{\circ}$ at different temperature can be calculated using the data in table 1 , and the equation $\Delta \mathrm{G}^{\circ}=\Delta \mathrm{H}^{\circ}-\mathrm{T} \Delta \mathrm{S}^{\circ}$ where $\Delta \mathrm{H}^{\circ}$ and $\Delta \mathrm{S}^{\circ}$ are the changes in the standard enthalpy in cal $/ \mathrm{mol}$ and standard of entropy in cal $/$ deg.mol 


$$
\begin{aligned}
\Delta \mathrm{G}^{\circ}(\text { Reaction }) & =\mathrm{G}^{\circ} \text { (products) }-\mathrm{G}^{\circ} \text { (Reactants) } \\
\mathrm{K} & =\exp \left(-\Delta \mathrm{G}^{\circ} / \mathrm{R} . \mathrm{T}\right) \ldots \ldots \ldots \ldots . . .
\end{aligned}
$$

Table (1): Gibbs free energy for some compounds.

\begin{tabular}{|c|c|}
\hline Compound & $\mathbf{G}^{\circ}=\mathbf{H}^{\circ}-\mathbf{T} . \mathbf{S}^{\circ}$ \\
\hline $\mathrm{CO}_{2}$ & $-94200-0.2^{*} \mathrm{~T}$ \\
\hline $\mathrm{CH}_{4}$ & $-16520+\left(12.25^{*} \mathrm{~T}^{*} \log (\mathrm{T})\right)-(15.62 * \mathrm{~T})$ \\
\hline $\mathrm{CO}$ & $-26700-20.95 * \mathrm{~T}$ \\
\hline $\mathrm{H}_{2} \mathrm{O}$ & $-58800+13.1^{*} \mathrm{~T}$ \\
\hline
\end{tabular}

All spontaneous reactions occur with a decrease in Gibbs free energy, while at equilibrium, Gibbs free energy change is zero. The products and reactants have the same Gibbs free energy and the reaction lacks a driving force in any direction. In an analogous way, a corresponding expression for the driving force for a process with constant volume can be derived [6].

There are two possibilities for solving for "W" and "Z".

The solution is mainly dependent on equilibrium relationships for reactions (1) and (2).

It is directly based on the definition of chemical equilibrium for reactions (1) and (2).

$\mathrm{P}_{\mathrm{N}_{2}}, \mathrm{P}_{\mathrm{CO}} \ldots \mathrm{P}_{\mathrm{i}}=$ Partial pressure of the component "i"

$\mathrm{P}_{\mathrm{t}}=$ total pressure or reformer working pressure.

$\mathrm{K}_{\mathrm{w}}=$ equilibrium constant for reaction (1), as a function of temperature.

$\mathrm{K}_{\mathrm{z}}=$ equilibrium constant for reaction (2), as a function of temperature.

$\mathrm{P}_{\mathrm{i}}=x_{\mathrm{i}} \cdot \mathrm{P}_{\mathrm{t}}$

The solution requires solving those two nonlinear equations using solver functionality and visual basic programming inside Microsoft excel [7], to get $\mathrm{W}$ and $\mathrm{Z}$ then calculate a set equations to get $x_{\mathrm{CH}_{4}}, x_{\mathrm{CO}_{2}}, x_{\mathrm{CO}}, x_{\mathrm{H}_{2}}, x_{\mathrm{N}_{2}}, x_{\mathrm{H}_{2} \mathrm{O}}$ in reformed gas.

Actually using the program representing this model requires only entering reformed gas temperature, pressure, steam to carbon ratio, equilibrium approach and natural gas composition and the program automatically computes the reformed gas composition.

Then the difference between theoretical and actual data from the plant gives a complete picture about the status of the catalyst. Because, if the difference is too big and slip methane in the reformed gas is very high in the actual compared to the theoretical data 
meaning that the catalyst is damaged and may need to be steamed or reduced or even completely changed to increase the efficiency of the reforming process [8].

The interface of the program was enhanced using VBA programming. [9]

\section{EXPERIMENTAL DATA}

In this article, data obtained on the steam reformer working at seven different cases at EZZ direct reduction plant (HYL III) are used. Table 2 shows the data of EZZ plant compared to the data obtained from the above-mentioned model in order to estimate the expected reformed gas composition by introducing the working pressure, temperature steam to carbon ratio fed in the reformer feed and the composition of natural gas entering the reformer.

Table (2): Case 1, 2, 3, 4 regarding reformed gas composition variation with steam to carbon ratio and temperature.

\begin{tabular}{|c|c|c|c|c|c|c|c|c|c|c|c|}
\hline \multicolumn{3}{|c|}{ Case1 } & \multicolumn{3}{|c|}{ Case2 } & \multicolumn{3}{|c|}{ Case3 } & \multicolumn{3}{|c|}{ Case4 } \\
\hline Temp ${ }^{\circ} \mathrm{C}$ & $\begin{array}{c}\text { STEAM } \\
\text { TO } \\
\text { CARBON }\end{array}$ & $\begin{array}{c}\text { Pressure } \\
\text { bar }\end{array}$ & Temp ${ }^{\circ} \mathrm{C}$ & $\begin{array}{c}\text { STEAM } \\
\text { TO } \\
\text { CARBON }\end{array}$ & $\begin{array}{c}\text { Pressure } \\
\text { bar }\end{array}$ & Temp ${ }^{\circ} \mathrm{C}$ & $\begin{array}{c}\text { STEAM } \\
\text { TO } \\
\text { CARBON }\end{array}$ & $\begin{array}{c}\text { Pressure } \\
\text { bar }\end{array}$ & Temp ${ }^{\circ} \mathrm{C}$ & $\begin{array}{l}\text { STEAM } \\
\text { TO } \\
\text { CARBON }\end{array}$ & $\begin{array}{c}\text { Pressure } \\
\text { bar }\end{array}$ \\
\hline 810 & 2.5 & 8.1576 & 815.3 & 2.6 & 8.1576 & 750 & 2.58 & 8.116812 & 827.18 & 2.56 & 8.116812 \\
\hline \multirow{2}{*}{ Compound } & \multicolumn{2}{|c|}{ Percentage \% } & \multirow{2}{*}{ Compound } & \multicolumn{2}{|c|}{ Percentage \% } & \multirow{2}{*}{ Compound } & \multicolumn{2}{|c|}{ Percentage \% } & Compoun & \multicolumn{2}{|c|}{ Percentage \% } \\
\hline & Model & actual & & Model & actual & & Model & actual & Compound & Model & actual \\
\hline $\mathrm{CH}_{4}$ & 3.220278 & 3.4 & $\mathrm{CH}_{4}$ & 2.683599 & 3.2 & $\mathrm{CH}_{4}$ & 7.489555 & 8.08 & $\mathrm{CH}_{4}$ & 2.247432 & 2.74 \\
\hline $\mathrm{CO}_{2}$ & 8.070007 & 7.6 & $\mathrm{CO}_{2}$ & 8.154994 & 7.8 & $\mathrm{CO}_{2}$ & 10.07666 & 9.73 & $\mathrm{CO}_{2}$ & 7.783985 & 7.58 \\
\hline $\mathrm{CO}$ & 14.4569 & 14.3 & $\mathrm{CO}$ & 14.44707 & 14.2 & $\mathrm{CO}$ & 10.92351 & 10.72 & $\mathrm{CO}$ & 15.06429 & 14.55 \\
\hline $\mathrm{H}_{2}$ & 74.25281 & 74.7 & $\mathrm{H}_{2}$ & 74.53979 & 74.8 & $\mathrm{H}_{2}$ & 71.51027 & 71.44 & $\mathrm{H}_{2}$ & 74.90429 & 75.13 \\
\hline $\mathrm{N}_{2}$ & 0 & 0 & $\mathrm{~N}_{2}$ & 0 & 0 & $\mathrm{~N}_{2}$ & 0 & 0 & $\mathrm{~N}_{2}$ & 0 & 0 \\
\hline $\mathrm{H}_{2} \mathrm{O}$ & 0 & 0 & $\mathrm{H}_{2} \mathrm{O}$ & 0 & 0 & $\mathrm{H}_{2} \mathrm{O}$ & 0 & 0 & $\mathrm{H}_{2} \mathrm{O}$ & 0 & 0 \\
\hline
\end{tabular}

Table (3): Case 5, 6, 7 regarding reformed gas composition variation with steam to carbon ratio and temperature.

\begin{tabular}{|c|c|c|c|c|c|c|c|c|}
\hline \multicolumn{3}{|c|}{ Case5 } & \multicolumn{3}{|c|}{ Case6 } & \multicolumn{3}{|c|}{ Case7 } \\
\hline $\operatorname{Temp}^{\circ} \mathrm{C}$ & $\begin{array}{c}\text { STEAM TO } \\
\text { CARBON }\end{array}$ & $\begin{array}{c}\text { Pressure } \\
\text { bar }\end{array}$ & Temp ${ }^{\circ} \mathrm{C}$ & $\begin{array}{l}\text { STEAM TO } \\
\text { CARBON }\end{array}$ & $\begin{array}{c}\text { Pressure } \\
\text { bar }\end{array}$ & Temp ${ }^{\circ} \mathrm{C}$ & $\begin{array}{c}\text { STEAM TO } \\
\text { CARBON }\end{array}$ & $\begin{array}{c}\text { Pressure } \\
\text { bar }\end{array}$ \\
\hline 810 & 2.83 & 8.25957 & 815 & 3.07 & 8.167797 & 815.34 & 2.81 & 8.147403 \\
\hline \multirow{2}{*}{ Compound } & \multicolumn{2}{|c|}{ Percentage $\%$} & Comnund & \multicolumn{2}{|c|}{ Percentage $\%$} & Comnound & \multicolumn{2}{|c|}{ Percentage $\%$} \\
\hline & Model & actual & compourna & Model & actual & compouria & Model & actual \\
\hline $\mathrm{CH}_{4}$ & 2.48004202 & 2.71 & $\mathrm{CH}_{4}$ & 2.211115 & 2.74 & $\mathrm{CH}_{4}$ & 2.24521417 & 2.84 \\
\hline $\mathrm{CO}_{2}$ & 8.81526546 & 8.29 & $\mathrm{CO}_{2}$ & 9.284175 & 7.58 & $\mathrm{CO}_{2}$ & 8.63658443 & 7.97 \\
\hline $\mathrm{CO}$ & 13.6874215 & 13.53 & $\mathrm{CO}$ & 13.14724 & 14.55 & $\mathrm{CO}$ & 13.9854327 & 13.76 \\
\hline $\mathrm{H}_{2}$ & 75.017271 & 75.49 & $\mathrm{H}_{2}$ & 75.27052 & 75.13 & $\mathrm{H}_{2}$ & 75.1327687 & 75.44 \\
\hline $\mathrm{N}_{2}$ & 0 & 0 & $\mathrm{~N}_{2}$ & 0 & 0 & $\mathrm{~N}_{2}$ & 0 & 0 \\
\hline $\mathrm{H}_{2} \mathrm{O}$ & 0 & 0 & $\mathrm{H}_{2} \mathrm{O}$ & 0 & 0 & $\mathrm{H}_{2} \mathrm{O}$ & 0 & 0 \\
\hline
\end{tabular}

\section{RESULTS AND DISCUSSION}

For better understanding of steam reformer performance, two graphs are drawn. The first (figure 2) shows the percentage of $\mathrm{CH}_{4}, \mathrm{CO}_{2}$ and $\mathrm{CO}$ in reformed gas as calculated by the model and the corresponding actual data from the plant versus steam to carbon ratio, keeping both working pressure and temperature constant .The second graph (figure 3 ) is for $\mathrm{H}_{2}$ percentage in reformed gas, keeping same working parameters as mentioned before. 
It is observed that $\mathrm{H}_{2}$ and $\mathrm{CO}_{2}$ percentage in reformed gas increases with increasing steam to carbon ratio while $\mathrm{CH}_{4}$ and $\mathrm{CO}$ decrease with increase of steam to carbon ratio.

The first graph (figure 4) shows the variation of the percentages of $\mathrm{CH}_{4}, \mathrm{CO}_{2}$ and $\mathrm{CO}$ in reformed gas as calculated by using the model and the actual plant data with temperature, keeping both, working pressure and steam to carbon ratio constant. While figure 5 depicts the variation of calculated and actual $\mathrm{H}_{2}$ concentration in reformed gas with temperature, keeping the other two variables constant (figure 4).

Also $\mathrm{H}_{2}$ and $\mathrm{CO}$ percentages in reformed gas increase with increasing temperature whereas $\mathrm{CH}_{4}$ and $\mathrm{CO}_{2}$ decrease.

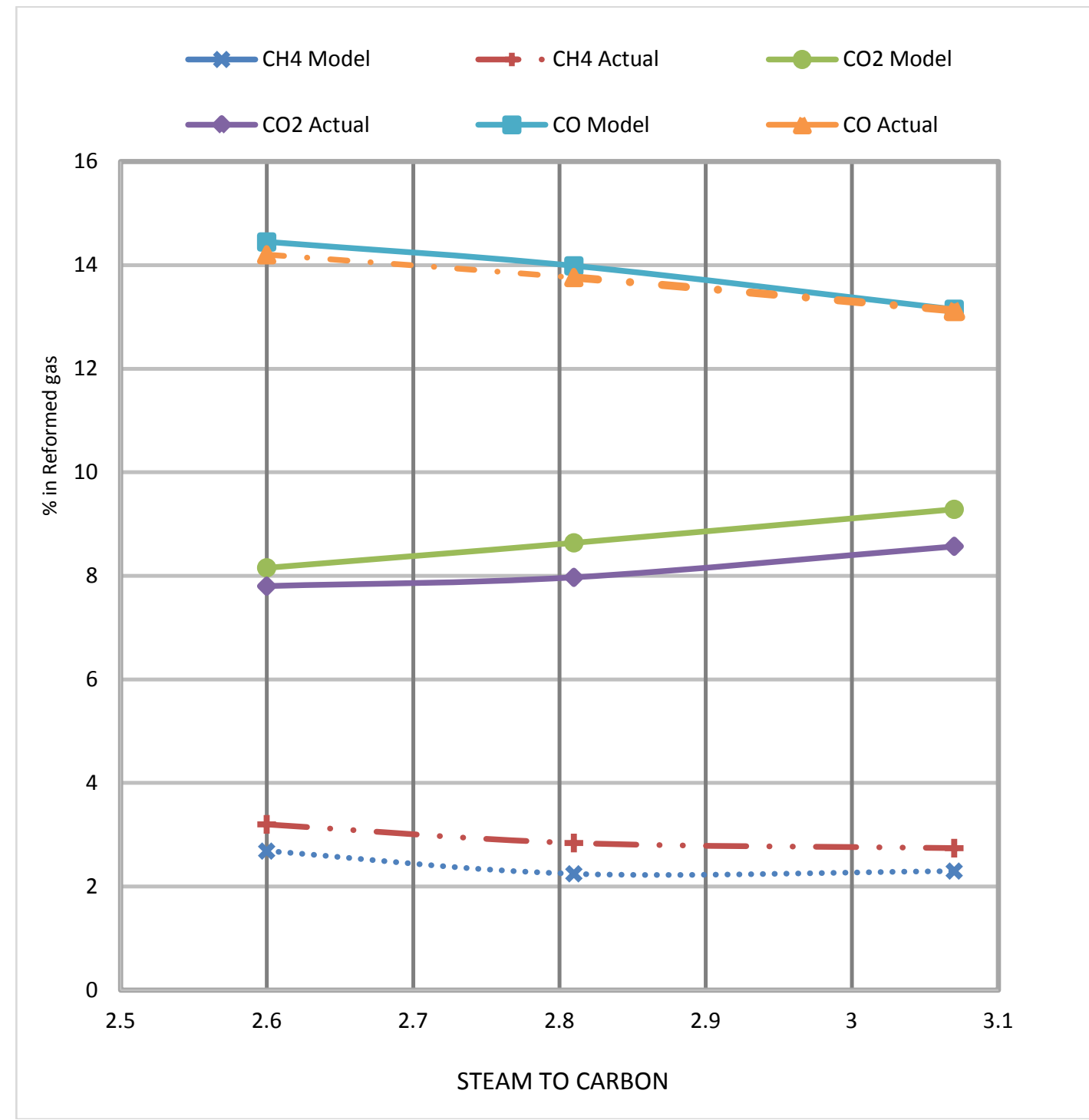

Fig. 2: Effect of STEAM TO CARBON ratio on $\mathrm{CH}_{4}, \mathrm{CO}_{2}$ and $\mathrm{CO}$ percentages in reformed gas at a constant temperature of $815^{\circ} \mathrm{C}$ and pressure of 8.15 $\mathrm{kg} / \mathrm{cm}^{2}$. 


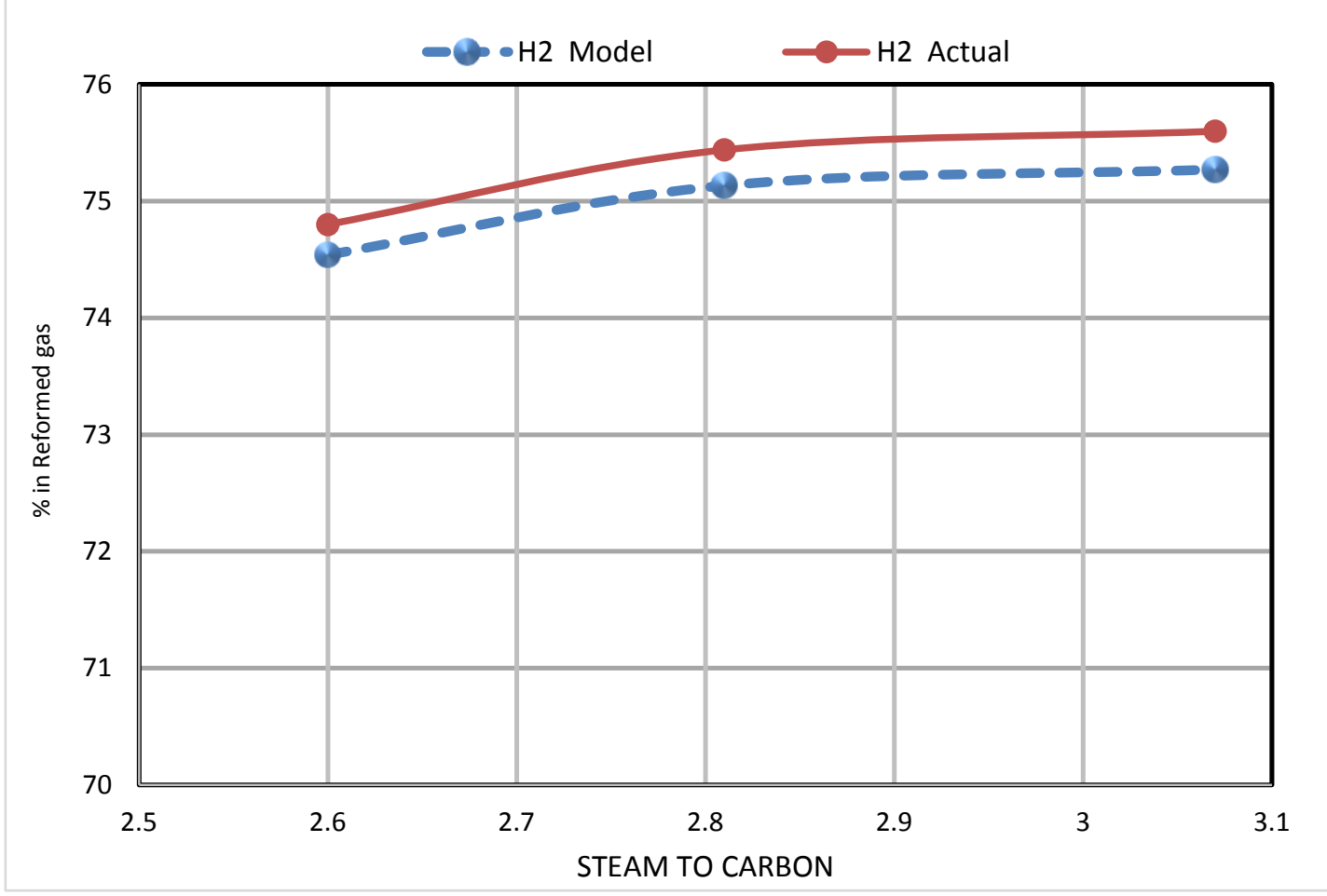

Fig. 3: Effect of STEAM TO CARBON ratio on $\mathrm{H}_{2}$ percentage in reformed gas at a constant temperature of $815^{\circ} \mathrm{C}$ and pressure of $8.15 \mathrm{~kg} / \mathrm{cm}^{2}$.

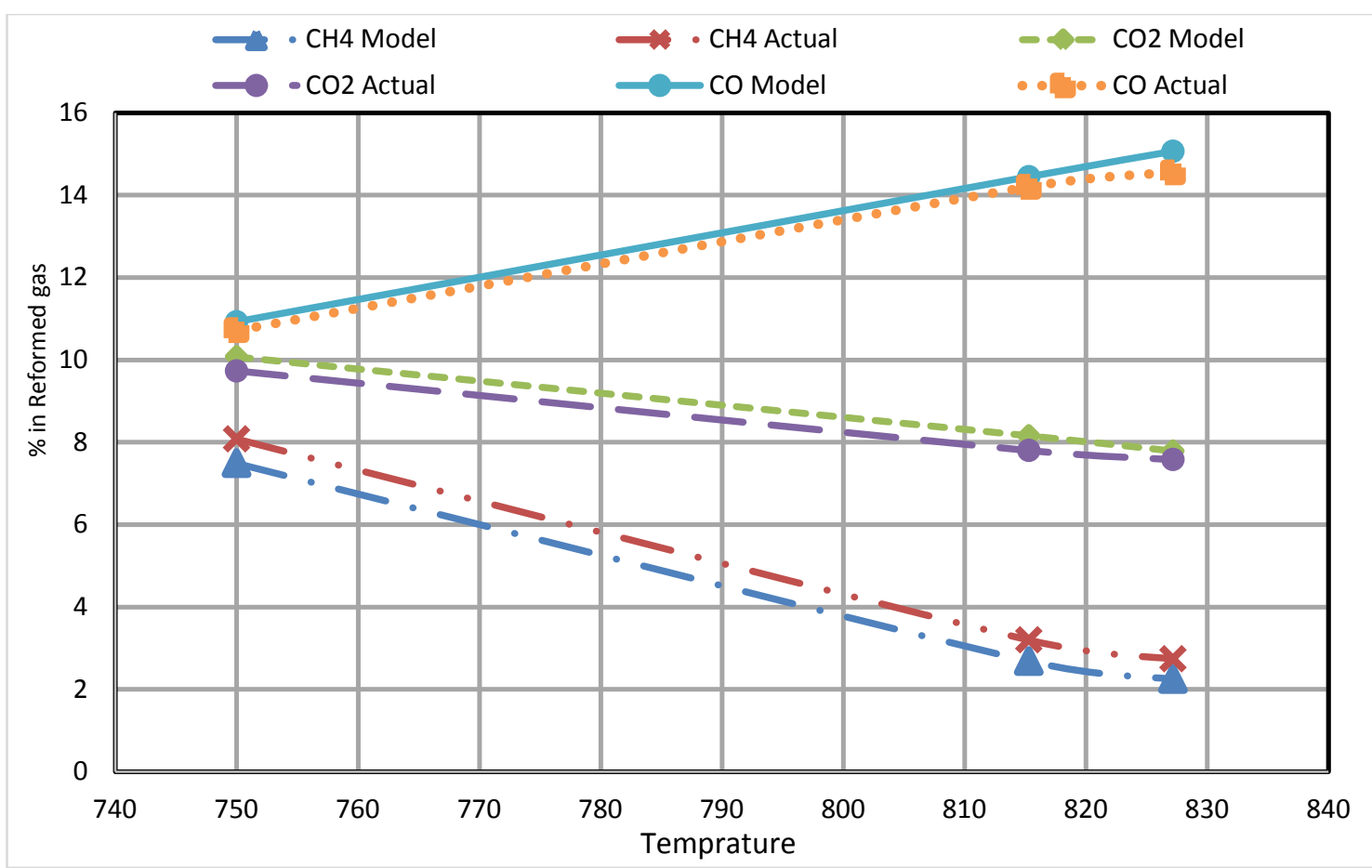

Fig. 4: Effect of temperature on $\mathrm{CH}_{4}, \mathrm{CO}_{2}$ and $\mathrm{CO}$ concentration in reformed gas at constant steam to carbon ratio of 2.6 and pressure of $8.15 \mathrm{Kg} / \mathrm{cm}^{2}$. 


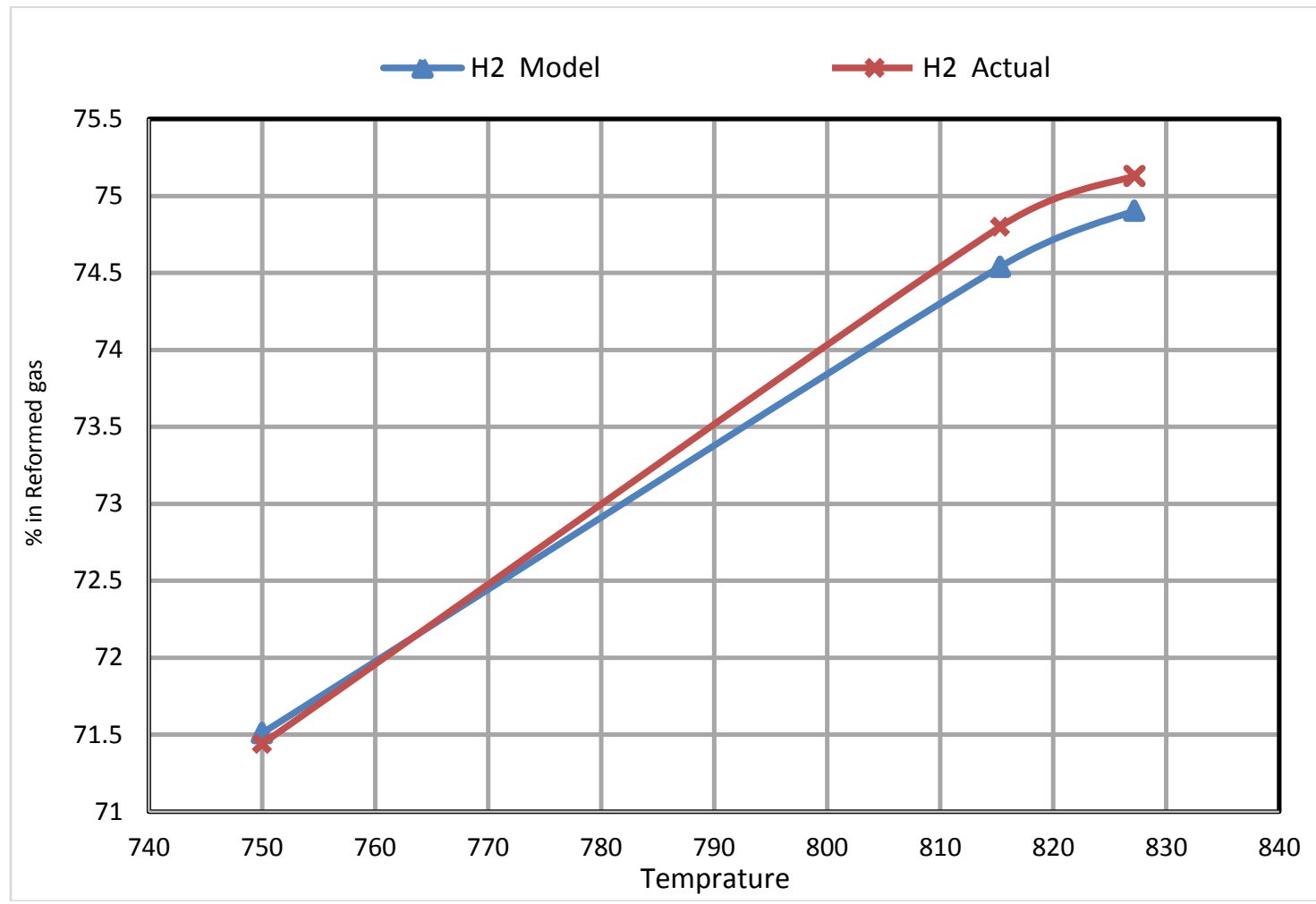

Fig. 5: Effect of temperature on $\mathrm{H}_{2}$ concentration in reformed gas at constant steam to carbon ratio of 2.6 and pressure of $8.15 \mathrm{Kg} / \mathrm{cm}^{2}$.

Reforming of hydrocarbon produces a syngas with $\mathrm{H}_{2} / \mathrm{CO}$ ratio ranging between 2.2 and 4.8 depending on the feed composition. Steam reforming is often conducted with natural gas, which is available worldwide, and at relative low price in large quantities. Steam Methane Reforming (SMR) proceeds in two steps, the reforming reaction in which methane reacts with steam producing $\mathrm{H}_{2}$ and $\mathrm{CO}$ is strongly endothermic (206 $\mathrm{kJ} / \mathrm{mol}$ ), and the water gas shift reaction leads to the conversion of $\mathrm{CO}$ to $\mathrm{H}_{2}$, which is slightly exothermic(- $41 \mathrm{~kJ} / \mathrm{mol})[10]$.

The present study shows that:

1 - Methane slip is proportional to $\mathrm{K}_{\mathrm{W}}$ that is inversely proportional to temperature.

2 - Methane slip is proportional to $\mathrm{P}_{\mathrm{t}}$.

3 - Methane slip is inversely proportional to steam to carbon ratio [11].

4 - The steam methane reforming reaction is strongly endothermic and is therefore favored by increasing temperature. Typical reformer outlet temperatures are in the range of $810-900^{\circ} \mathrm{C}$. As the temperature increases, the hydrogen yield increases, which is reflected in a decrease of methane concentration in the reformer effluent, known as methane slip. The higher the $\mathrm{H}_{2}$ yield, the lesser the amount of feedstock that will be consumed [11]. 
5 - $\mathrm{CO}$ concentration is not dependent on reformer working pressure.

6 - Higher steam to carbon ratio gives lower CO content.

7 - Higher steam to carbon ratio gives higher $\mathrm{CO}_{2}$ content.

8 - High exit temperature gives more $\mathrm{CO}$ and less $\mathrm{CO}_{2}$ because of the exothermic nature of the water-gas shift reaction [11].

The theoretical calculations are in accord with the respective practical data collected at different operation parameters of EZZ direct reduction plant at Suez Elsokhna.

The study is particularly useful for countries where natural gas prices dominate operating cost. The most important parameters to influence natural gas consumption are:

- Methane slip.

- Steam-to-carbon ratio.

- Natural gas composition [12].

\section{Conclusions}

The theoretical calculations are in accord with the respective practical data collected at different operation parameters of EZZ direct reduction plant at Suez Elsokhna that is mean that this study is helpful in Identification and optimization of process parameters and the optimization of process/design parameters for the minimization of natural gas consumption and tuning of the whole operation.

\section{Nomenclature}

$\mathrm{K}_{\mathrm{w}}$ : Equilibrium constant for steam-methane reaction

$\mathrm{K}_{\mathrm{z}}$ : Equilibrium constant for water gas shift reaction P: Reformer pressure

$\mathrm{P}_{\mathrm{CO}}, P_{\mathrm{H}_{2}}, P_{\mathrm{N}_{2}}, P_{\mathrm{H}_{2} \mathrm{O}}$ Partial pressures of $\mathrm{CO}, \mathrm{H}_{2}, \mathrm{CH}_{4}$ and $\mathrm{H}_{2} \mathrm{O}$,

$\mathrm{C}$ : (All carbon becomes $\mathrm{CO}$ ),

A: (all hydrogen becomes $\mathrm{H}_{2}$ except the Hydrogen combined as $\mathrm{H}_{2} \mathrm{O}$ ),

$\mathrm{B}$ : $\left(\mathrm{H}_{2} \mathrm{O}\right.$ is equal to all the oxygen not combined as $\left.\mathrm{CO}\right)$.

I: Inert gas.

$\mathrm{D}=\mathrm{A}+\mathrm{C}+\mathrm{I}$,

$\mathrm{C}_{1} \mathrm{C}_{2} \ldots ; \mathrm{Cn}$ : Mole fractions of $\mathrm{CH}_{4} \ldots \mathrm{Cn} \mathrm{H}_{2 \mathrm{n}+2}$ in the natural gas fed.

$x_{\mathrm{CO}_{2}}, x_{\mathrm{CO}}, x_{\mathrm{H}_{2}}, x_{\mathrm{N}_{2}}, x_{\mathrm{H}_{2} \mathrm{O}}[=]$ mole fractions of $\mathrm{CO}_{2} \mathrm{CO}, \mathrm{H}_{2} \mathrm{~N}_{2}$ and $\mathrm{H}_{2} \mathrm{O}$ respectively in the natural gas fed,

r: Steam/carbon molar ratio fed to the reformer: STEAM TO CARBON,

$\mathrm{W}$ : is moles of $\mathrm{CH}_{4}$ produced by reaction,

$\mathrm{Z}$ : is moles of $\mathrm{CO}_{2}$ produced by reaction,

F: total flow

$\mathrm{p}_{\mathrm{N} 2}, \mathrm{p}_{\mathrm{CO}} \ldots \mathrm{p}_{\mathrm{i}}=$ Partial pressure of the " $\mathrm{i}$ " component,

$\mathrm{P}_{\mathrm{t}}=$ Total pressure or reformer working pressure.

$\mathrm{P}_{\mathrm{i}}=\mathrm{x}_{\mathrm{i}} . \mathrm{P}_{\mathrm{T}}=$ component $\left(\mathrm{H}_{2}, \mathrm{CO}\right.$, etc. $)$ 


\section{Acknowledgment}

The authors are grateful to EZZ Rolling Mills for the generous permission to use the plant data in the present study.

\section{REFERENCES}

[1] Roohollah; Ashrafian; Mahla; Rashidian; Amiri, M.; Urazgaliyeva, G. and Khatibi, M.: "Direct reduction of iron ore using natural gas". Trondheim, p. 3, Nov. (2011).

[2] Morales, R. G. and Prenzel, M.: "XXXII ABM iron-making seminar". Vitória-ES, Brazil, p. 3, Nov. 6-8, (2002).

[3] Morales, R. G.: "Article for HYL Boiuness Airus institute". Argentina, p. 6, (1999).

[4] Broadhurst, P. and Hinton, G.: "A study of fuel gas is an attractive feedstock for hydrogen production, but appropriate catalysts and temperature control are needed to address high olefin levels". Johnson Matthey catalysts catalysis, p. 1, (2012).

[5] Coudurier, L.; Wilkomirsky, I. and Hopkins, D. W.: "Fundamentals of metallurgical process". $2^{\text {nd. }}$ Ed., Pergamon press, pp. 332-337, (1985).

[6] Seetharaman, S.: "Fundamentals of metallurgy". $1^{\text {st. }}$ published 2005, Woodhead publishing limited and CRC Press LLC (C) Woodhead publishing limited, p. 45, (2005).

[7] Deshpande, V. and Saha, S.: "Study of estimating reformed gas composition in a primary reformer when the feed is a natural gas containing higher hydrocarbons". www.digitalrefining.com/article/1000779, Gas, p. 3, (2013).

[8] Ali, M. S.; Zahangir, S. M.; Badruddoza, A. Z. M. and Haque, M. R.: "A study of effect of pressure, temperature and steam/natural gas ratio on reforming process for ammonia production". Department of chemical engineering, Bangladesh University of engineering and technology, p. 5, (1889).

[9] Roman, S.: "Ph. D. Writing Excel Macros with VBA". 2 ${ }^{\text {nd. }}$ Ed., O'Reilly publications, pp. 35-37, Jun. (2002).

[10] Roussière, Th. L.: "A study of catalytic reforming of methane in the presence of $\mathrm{CO}_{2}$ and $\mathrm{H}_{2} \mathrm{O}$ at high pressure". Dr. Rer. Nat thesis, Faculty of chemistry and biosciences, Karlsruhe institute of technology (KIT), p. 7, Oct. (2013).

[11] Hawkins, G. B.: "Steam reforming approach to equilibrium presentation". Vulcan catalyst process technology consultancy, www.gbhenterprises.com, pp. 4-10, (2012).

[12] Rajyalakshmi, S.; Patwardhan, K. and P V Balaramakrishna; Larsen and Toubro: "A study of modeling optimization of process and design parameters for minimizing natural gas consumption in hydrogen production by steam reforming". PTQ Q1, p. 2, www.digitalrefining.com/article/1000339, (2012). 